\title{
PENGARUH PEMBERIAN BARUASA KACANG GUDE PADA BERAT BADAN DAN TINGGI BADAN ANAK SEKOLAH DASAR DI KECAMATAN BONTORAMBA
}

\author{
Resti Kusumarini Samben \\ Program Studi Ilmu Gizi, Universitas Dhyana Pura \\ Email: restisamben@undhirabali.ac.id
}

\begin{abstract}
ABSTRAK
Gizi kurang merupakan masalah global terutama pada negara-negara berkembang. Penelitian ini bertujuan untuk menilai pengaruh pemberian baruasa kacang gude terhadap berat badan dan tinggi badan siswa sekolah dasar. Baruasa kacang gude dapat dimanfaatkan sebagai jajanan sumber protein yang cukup tinggi karena mengandung protein sebesar 20,70\%. Desain penelitian adalah penelitian eksperimen semu menggunakan rancangan Pretest-Postest dengan teknik pengambilan sampel secara purposif. Penelitian ini melibatkan 60 siswa yang dibagi dalam tiga kelompok yakni, kelompok baruasa kacang gude+obat cacing, kelompok baruasa, dan kelompok obat cacing. Satu minggu sebelum intervensi kelompok pertama diberi obat cacing pirantel pamoat dosis $10 \mathrm{ml}$, kemudian diberi intervensi baruasa kacang gude $60 \mathrm{~g} / \mathrm{hr}$, kelompok kedua diberikan baruasa kacang gude sebanyak $60 \mathrm{~g} / \mathrm{hr}$, dan kelompok ketiga diberikan obat cacing pirantel pamoat dosis $10 \mathrm{ml}$. Pemberian baruasa pada kelompok pertama dan kedua dilakukan selama 60 hari. Pengukuran $\mathrm{BB}$ dan $\mathrm{TB}$ siswa dilakukan satu minggu sebelum dan satu minggu setelah pelaksanaan intervensi berakhir. BB diukur menggunakan timbangan camry, sedangkan tinggi badan menggunakan microtoice. Hasil penelitian menunjukkan bahwa persentase perubahan rata-rata $\mathrm{BB}$ dan TB siswa pada kelompok baruasa+obat cacing lebih tinggi dibanding kelompok perlakuan lainnya dan berbeda secara bermakna. Pemberian baruasa kacang gude+obat cacing dapat menaikkan berat badan dan tinggi badan siswa sekolah dasar.
\end{abstract}

Kata Kunci : Baruasa kacang gude, berat badan, tinggi badan, siswa sekolah dasar.

\begin{abstract}
Malnutrition is a global problem, especially in developing countries. The aim of the research was to asses the effect of giving baruasa pigeon pea on weight and height of elementary school students. The research was a quasi-experiment study using pretest-posttest design. The samples were selected using purposive sampling technique consisting of 60 students divided into three groups, i.e. baruasa pigeon pea+anthelmintic, baruasa group, and anthelmintic group. One week before intervention, the first group was given pyrantel pamoate anthelmintic with a dose of $10 \mathrm{ml}$. Then it was given intervention of baruasa pigeon pea $60 \mathrm{~g} / \mathrm{hr}$. The second group was given baruasa pigeon pea $60 \mathrm{~g} / \mathrm{hr}$, and the third group was pyrantel pamoate anthelmintic with a dose of $10 \mathrm{ml}$. The first and the second groups were given baruasa for 60 days. The measurement of weight and height students was done one week before and one week after the implementation of intervension ends. Weight was measured using camry scale, while height was measured using microtoice. The result of the research indicate that the percentage of average change of students weight and height in baruasa + anthelmintic group is higher than the one in other treatment groups and they are different significantly.
\end{abstract}

Keyword : baruasa pigeon pea, weight, height, elementary students

\section{PENDAHULUAN}

Data Riskesdas 2013, secara nasional, prevalensi berat kurang (underweight) pada balita menurut indikator $\mathrm{BB} / \mathrm{U}$ adalah 19,6 persen, terdiri atas 5,7 persen gizi buruk dan 13,9 persen gizi kurang. Sementara prevalensi kurus (menurut IMT/U) pada anak umur 5-12 tahun adalah 11.2 persen, terdiri dari 4,0 persen sangat kurus dan 7,2 persen kurus. Hasil survei yang dilakukan mahasiswa pasca sarjana gizi Unhas tahun 2014 terhadap 3 Sekolah dasar di kecamatan
Bontoramba yaitu SD 29 Cinniayo, SD 124 Bontoramba dan SD 18 Maero didapatkan bahwa terdapat 33\% siswa sangat kurus dan 20\% siswa kurus.

Hasil survey pendahuluan yang dilakukan di 6 sekolah di kabupaten Jeneponto dengan melakukan recall 24 jam di dapatkan bahwa berdasarkan $\mathrm{AKG}$ tahun 2013 masih didapatkan anak-anak yang mengalami kekurangan protein dan zat besi. Jumlah kekurangan protein yang didapatkan adalah sebanyak 12,11-23,31 gr atau sekitar 21,64-41,64\% 
dari total AKG yang di anjurkan untuk anak usia 10-12 tahun adalah 56 gram. Negara-negara berkembang selama dua puluh tahun sebelum 1971 lebih berpusat pada suplai protein untuk menanggulangi kekurangan protein dan menghindari krisis protein. Semboyan-semboyan dikeluarkan untuk menggiatkan produksi bahanbahan berprotein dari sumber-sumber yang tidak umum seperti sisa minyak biji-bijian, tepung ikan, daun-daun rumput dan organisme bersel tunggal seperti bakteri, ragi dan algae (Ulasaswini, 2015).

Perbaikan status gizi anak usia sekolah perlu dilakukan dengan memanfaatkan bahan pangan yang berasal atau yang mudah didapat di daerah setempat. Hal ini didasari bahwa strategi pendekatan berbasis pangan (food based approach) merupakan intervensi gizi yang mempunyai daya terima tinggi, efektif, dan berbiaya rendah sehingga berperan dalam program gizi berkelanjutan (sustainable) (Ulasaswini, 2015).

Komposisi kimia kacang gude mengandung protein tinggi. Kacang gude lebih unggul daripada kacang kedelai pada karbohidrat dan vitamin A. Protein 22,07 g; Lemak 1,13 gr; Karbohidrat 10,16 gr; Besi 6,787 mg; Vitamin A 150,0 SI; dan Vitamin C 5,0 mg.

Kacang gude sumber yang baik untuk serat kasar, besi $(\mathrm{Fe})$, sulfur, kalsium, kalium (K), mangan dan vitamin larut dalam air terutama tiamin, riboflavin, niacin Gude mengandung lebih banyak mineral, sepuluh kali lebih banyak lemak, lima kali lebih banyak vitamin A dan dan tiga kali lebih banyak vitamin $\mathrm{C}$ dari kacang polong biasa (Sharma, 2011).

Penelitian ini bertujuan untuk menilai pengaruh pemberian baruasa kacang pada berat badan dan tinggi badan siswa sekolah sekolah dasar.

\section{METODE}

\section{Lokasi Penelitian}

Penelitian dilakukan di 8 sekolah di Kecamatan Bontoramba, Kabupaten Jeneponto.

\section{Jenis Penelitian dan Desain Penelitian}

Jenis penelitian ini adalah Quasi experiment dengan rancangan pre-test post-test with control group design. Dalam penelitian ini digunakan tiga kelompok perlakuan yaitu: kelompok baruasa kacang gude + obat cacing, kelompok baruasa, kelompok obat cacing. Pemberian dilakukan 6 kali seminggu dalam 8 minggu. Variabel bebas dalam penelitian ini adalah pemberian kacang gude, dan variabel terikat dalam percobaan ini adalah perubahan BB dan TB setiap kelompok setelah menerima perlakuan. Adapun variabel yang dikontrol dalam penelitian ini antara lain umur siswa, dan cara pemberian baruasa kacang gude pada sampel.

\section{Subjek Penelitian}

Subjek yang digunakan dalam penelitian ini siswa sekolah dasar kelas 4,5 , dan 6 yang berasal dari 8 sekolah dasar di Kecamatan Bontoramba, Kabupaten Jeneponto. Subjek tidak sedang mengalami sakit diare, malaria, dan infeksi lainnya selama dilakukan penelitian.

\section{Sampel atau Subjek Penelitian}

Anak SD yang memenuhi kriteria inklusi dijadikan sampel penelitian. Sampel dikelompokkan menjadi 3 kelompok, yaitu: kelompok Baruasa Kacang Gude+ Obat cacing (intervensi 1), kelompok baruasa(intervensi 2), dan kelompok obat cacing (intervensi 3). Selanjutnya sampel pada kelompok intervensi 1 dan 3 mendapatkan obat cacing pyrantel pamoate dosis $10 \mathrm{mg} / \mathrm{Kg}$ berat badan satu minggu sebelum intervensi dengan tujuan untuk menghomogenkan sampel.

Sebelum intervensi dimulai semua sampel diberikan recall konsumsi makanan sampel selama 24 jam. Kelompok intervensi 1 dan 2 mendapatkan kue tradisional baruasa kacang gude dengan komposisi yang disesuiakan dengan AKG anak sekolah yang telah melalui uji hedonic dan organoleptic di laboratorium terpadu. Baruasa kacang gude terdiri dari campuran tepung kacang gude $75 \%$, tepung beras $25 \%$, gula merah, telur, dan baking powder yang cara pembuatannya sama dengan pembuatan baruasa tradisonal di daerah setempat. 100 gram baruasa mengandung $\mathrm{E}=$ $387.11 \mathrm{kkal}, \mathrm{KH}=69.76 \mathrm{gr}$, Lemak $=7.75 \mathrm{gr}$, dan $\mathrm{Fe}=7.83 \mathrm{mg}$ yang dinilai cukup baik sebagai makanan tambahan anak sekolah. Kelompok 3 hanya mendapatkan obat cacing. Pada minggu kelima dan kesembilan kembali dilakukan recall konsumsi dengan FFQ semi kuantitatif. Setelah 8 minggu intervensi dilakukan lagi pemeriksaan $\mathrm{BB}$ dan TB. Kepatuhan konsumsi di kontrol dengan menggunakan kartu kontrol dengan bantuan guru dan orang tua siswa, untuk kelompok intervensi pertama dan kedua di habiskan sebelum pulang sekolah untuk memudahkan pengontrolan dan mengurangi bias.

\section{Alat dan Bahan Penelitian}

Alat yang digunakan dalam penelitian ini adalah timbangan BB merk camry yang sudah dikalibrasi sedangkan untuk $\mathrm{TB}$ menggunakan microtoice yang sudah dikalibrasi. Instrumen yang dipakai untuk penelitian ini adalah formulir data identitas anak SD untuk penyaringan awal, formulir kesediaan orang tua menjadi responden, formulir FFQ-SK makanan anak SD, kuisioner data 
anak dan keluarga, dan formulir untuk memantau kepatuhan konsumsi baruasa kacang gude.

\section{Analisis Data}

Pengolahan data dilakukan dengan menggunakan komputer program SPSS 16.0 untuk melakukan analisis data dengan uji univariate dan bivariat. Uji univariate dilakukan pada masingmasing variabel untuk melihat gambaran umum distribusi dan frekuensi. Sedangkan Uji bivariate dilakukan dengan membandingkan hasil pemeriksaan $\mathrm{BB}$ dan $\mathrm{TB}$ sebelum dan sesudah diberikan intervensi dengan menggunakan uji $t$ berpasangan dan annova untuk menguji perlakuan antar kelompok, dengan nilai kepercayaan 95\% (alpha $=5 \%)$. Jika sebaran data pada dua variabel terdistribusi normal maka menggunakan uji $T$, jika tidak terdistribusi normal menggunakan signwilcoxon signed test. Pada uji antar kelompok lebih dari 3 kelompok., jika data terdisrbusi normal menggunakan uji annova, sedangkan jika data terdistribusi tidak normal menggunakan uji Kruskal Wallis $H$.

Uji normalitas data pada penelitiaan ini mennunjukkan sebaran data 2 variabel pada kelompok baruasa+obat cacing dan kelompok obat cacing tidak terdisribusi normal sehingga menggunakan signwilcoxon signed test sedangkan pada kelompok baruasa sebaran data 2 variabel terdistribusi normal sehingga menggunakan uji $\mathrm{T}$. Uji antar 3 kelompok menggunakan Kruskal Wallis $H$ karena sebaran data antar kelompok tidak terdistribusi normal.

Selanjutnya data yang telah diperoleh disajikan dalam bentuk tabel dan grafik disertai dengan narasi. Penelitian ini adalah quasy eksperimen untuk mengetahui efek pemberian kacang gude (Cajanus Cajan) terhadap perubahan BB dan TB anak sekolah dasar kelas 4,5 dan 6 di Kec. Bontoramba, Kab. Jeneponto.

\section{HASIL DAN PEMBAHASAN}

Siswa dalam 2 kelompok perlakuan diberikan intervensi pemberian baruasa kacang gude selama 60 hari, sedangkan siswa dalam kelompok 3 tetap dalam pengamatan untuk menilai asupan dan pola makan. Tidak ada subjek penelitian yang mengalami drop out hingga akhir penelitian. Adapun rerata hasil pengukuran BB dalam penelitian ini menunjukkan bahwa setelah perlakuan (post) pada kelompok baruasa+obat cacing terjadi peningkatan BB (5.39\%) yang signifikan dengan nilai $\mathrm{p}=0.00<0.05$

Tabel 1. Rerata Perubahan Berat Badan (Pre-Post) siswa Sekolah Dasar di Kec. Bontoramba Kab.Jeneponto

\begin{tabular}{lcccc}
\hline & \multicolumn{2}{c}{ Berat Badan } & \\
\multicolumn{1}{c}{ Kelompok } & Pre mean \pm SD $(\mathrm{kg})$ & $\begin{array}{c}\text { Post mean } \\
\pm \mathrm{SD}(\mathrm{kg})\end{array}$ & $\begin{array}{c}\Delta \text { mean } \\
(\%)\end{array}$ & Nilai p \\
\hline Baruasa+ & & $24.24 \pm 4.96$ & 1.24 & $0.000^{\mathrm{a}}$ \\
Obat cacing $(\mathrm{n}=20)$ & $23.00 \pm 4.55$ & & $(5.39)$ & \\
Baruasa $(\mathrm{n}=20)$ & $23.37 \pm 5.65$ & $24.32 \pm 5.90$ & 0.95 & $0.000^{\mathrm{b}}$ \\
& & & $(4.06)$ & \\
Obat Cacing $(\mathrm{n}=20)$ & $24.52 \pm 5.29$ & $25.35 \pm 6.02$ & $0.83(0.03)$ & $0.051^{\mathrm{b}}$ \\
Nilai $\mathrm{p}$ & $0.300^{\mathrm{c}}$ & $0.537^{\mathrm{c}}$ & $0.85^{\mathrm{c}}$ & \\
\hline
\end{tabular}

${ }^{\mathrm{a}}$ Wilcoxon ${ }^{\mathrm{c}}$ Kruskal Wallis ${ }^{\mathrm{b}} \mathrm{Uji} \mathrm{T}$

Pada tabel 1. Menunjukkan rerata perubahan berat badan siswa pada kelompok baruasa+obat cacing dan kelompok baruasa meningkat dengan nilai $\mathrm{p}<0.05$, dibandingkan dengan kelompok perlakuan lainnya.
Perubahan rerata tinggi badan pada ketiga kelompok perlakuan dapat di lihat pada tabel 2 . berikut:

Tabel 2. Rerata Perubahan Tinggi Badan Pre-Post siswa Sekolah Dasar

\begin{tabular}{|c|c|c|c|c|}
\hline \multicolumn{5}{|c|}{$\begin{array}{l}\text { Tinggi Badan } \\
\end{array}$} \\
\hline Kelompok & Pre mean $\pm \mathrm{SD}(\mathrm{cm})$ & $\begin{array}{c}\text { Post mean } \pm \text { SD } \\
(\mathrm{cm})\end{array}$ & $\begin{array}{c}\Delta \text { mean } \\
(\%)\end{array}$ & Nilai p \\
\hline Baruasat & $127.58 \pm 8.50$ & $128.60 \pm 8.30$ & 1.02 & $0.000^{\mathrm{a}}$ \\
\hline $\begin{array}{l}\text { bat cacing }(n=20) \\
\text { Baruasa }(n=20)\end{array}$ & $125.22 \pm 5.52$ & $125.87 \pm 8.45$ & $\begin{array}{l}(0.79) \\
0.65 \\
(0.51)\end{array}$ & $0.000^{\mathrm{a}}$ \\
\hline Obat Cacing $(n=20)$ & $126.24 \pm 7.05$ & $126.73 \pm 7.22$ & $\begin{array}{c}0.49 \\
(0.38)\end{array}$ & $0.001^{\mathrm{a}}$ \\
\hline Nilai $\mathrm{p}$ & $0.653^{\mathrm{b}}$ & $0.547^{\mathrm{b}}$ & $0.44^{\mathrm{c}}$ & \\
\hline
\end{tabular}




\section{${ }^{\mathrm{a}}$ Wilcoxon $\quad{ }^{\mathrm{c}}$ Kruskal Wallis ${ }^{\mathrm{b}}$ Anova}

Tabel 2 menunjukan bahwa persentase rerata perubahan tinggi badan pada kelompok baruasa mengalami peningkatan sebesar $1.02 \mathrm{~cm}(0.79 \%)$ lebih tinggi di banding kedua kelompok perlakuan lainnya dimana kelompok baruasa $0.51 \%$ dan kelompok obat cacing hanya sebesar $0.38 \%$. Pada ketiga kelompok perlakuan masing-masing ada perubahan tinggi badan yang signifikan ditunjukkan dengan nilai $\mathrm{p}$ masing-masing $<0.05$ Penelitian ini menunjukkan bahwa pemberian baruasa kacang gude kepada siswa dapat meningkatkan rata-rata $\mathrm{BB}$ dan $\mathrm{TB}$. Meskipun, berdasarkan hasil uji statsitik antara 3 kelompok perlakuan tidak menunjukkan hasil yang signifikan.

Baruasa kacang gude tinggi akan kandungan zat gizi. 100 gram baruasa dengan kandungan $75 \%$ kacang gude mengandung $\mathrm{E}=387.11 \mathrm{kkal}, \mathrm{KH}=$ 69.76 gr, Lemak = 7.75 gr, dan $\mathrm{Fe}=7.83 \mathrm{mg}$ yang dinilai cukup baik sebagai makanan tambahan anak sekolah (Labkes,2015).

Kacang gude juga telah di formulasikan sebagai MP-ASI dengan penambahan tepung tapioka yang dapat menghasilkan produk MPASI yang mengandung kalori sebesar 436.67 kkal, $21.36 \%$ protein, $11.67 \%$ lemak, dan $4.03 \%$ serat kasar yang dinilai cukup sebagai makanan tambahan untuk balita (Purnamasari,2014).

Biji kacang gude mengandung protein sebesar $20.70 \%$, sehingga dapat dimanfaatkan sebagai sumber protein nabati selain kedelai bagi masyarakat di daerah-daerah yang kering. Diversifikasi produk kacang gude seperti kue baruasa dapat meningkatkan kesukaan masyarakat terhadap kacang gude sehingga kacang gude mempunyai potensi untuk kudapan anak sekolah.

Salah satu dampak dari pemberian obat cacing yang dilakukan sebelumnya mampu menghilangkan parasit dalam tubuh. Pemberian obat cacing pada populasi yang rawan infeksi kecacingan dapat meningkatkan nafsu makan, kadar $\mathrm{Hb}$, dan penyerapan zat-zat gizi dapat lebih optimal (Gutema, 2014).

Beberapa penelitian mengungkapkan penambahan kacang-kacangan baik sebagai bahan utama atau tambahan dalam pembuatan makanan tambahan untuk balita dan anak-anak terbukti dapat meningkatkan nilai zat gizi. Penambahan tepung kacang merah dalam pembuatan biskuit dengan berbagai variasi memberi pengaruh dari segi tekstur dan rasa maupun kandungan zat gizi. Penambahan tepung kacang merah dalam pembuatan biskuit juga memberikan peningkatan jumlah protein dan serat pada biskuit (Ulasaswini, 2015).

Salah satu upaya untuk meningkatkan indeks massa tubuh yaitu meningkatkan konsumsi protein.
Asupan protein mempengaruhi komposisi tubuh melalui perubahan sintesis protein, akan menyebabkan peningkatan keseimbangan protein ke arah positif, sehingga sintesis protein akan meningkat. Konsumsi makanan tinggi protein merupakan salah upaya untuk meningkatkan asupan protein (Harna,2017).

Penambahan kacang gude pada pisang signifikan $(\mathrm{p}<0,05)$ meningkatkan protein 2,40 14,48 \pm 0.11. Demikian pula, abu, lemak dan serat meningkat. Penambahan kacang gude juga meningkatkan semua asam amino hingga 37,5\%, juga pada kalium, fosfor, natrium, magnesium dan kalsium. Hasil penelitian menunjukkan bahwa pencampuran dari kacang gude dengan pisang mentah akan menghasilkan makanan dari kepadatan nutrisi yang seimbang untuk orang dewasa (Ulasaswini, 2015).

Protein merupakan suatu zat gizi yang amat penting bagi tubuh, sebagai zat untuk meningkatkan penyerapan Fe. Angka kebutuhan gizi rata-rata yang dianjurkan bagi anak usia sekolah 7-12 tahun yaitu protein sebesar 45-50 gram per orang per hari. Berpedoman pada program PMT-AS tahun 2011, makanan tambahan setidaknya mampu menyediakan $10 \%$ dari total kebutuhan protein sesuai dengan usia anak sekolah tersebut. Dengan kata lain kandungan gizi pada setiap makanan tambahan setidaknya mengandung protein sebesar 4,5-5 gram. Berdasarkan uraian di atas, dapat diketahui bahwa dalam tiap 100 gram baruasa dengan penambahan tepung kacang gude sebesar $75 \%$ telah mampu menyediakan protein $20 \%$ dari total kebutuhan protein. Dengan demikian, maka baruasa tersebut telah sesuai dengan standar yang disyaratkan oleh program PMT-AS tahun 2011 sebagai makanan tambahan anak sekolah (Ulasaswini, 2015).

Prinsip makanan tambahan anak sekolah antara lain : 1. Bentuk Makanan Tambahan tidak berupa makanan lengkap seperti nasi dan lauk tetapi berupa makanan kudapan, dengan memperhatikan aspek mutu dan keamanan pangan. 2. Bahan Pangan kudapan yang dilakukan sendiri diharapkan dapat memenuhi syarat mutu, nilai gizi, kebersihan dan harga (Raisita, 2013).

PMT-AS sebaiknya menggunakan bahan pangan lokal yang diolah menjadi kudapan yang diberikan kepada siswa. Pengolahan kudapan yang dilakukan sendiri diharapkan dapat memenuhi syarat mutu, nilai gizi, kebersihan dan harga (Raisita, 2013)

\section{KESIMPULAN DAN SARAN}

Disimpulkan bahwa pemberian baruasa kacang gude dapat meningkatkan BB dan TB 
siswa, namun secara statistik tidak menunjukkan hasil yang signifikan. Disarankan untuk penelitian selanjutnya perlu dikaji lebih dalam mengenai efek pemberian baruasa terhadap hormon IGF-1 yang berperan dalam pertumbuhan.

\section{DAFTAR PUSTAKA}

Gizi, Pascasarjana. (2014). Survei gizi \& kesehatan ibu dan anak Baduta di kecamatan bontoramba Kabupaten jeneponto. Universitas Hasanuddin.

Gutema, B. (2014). Anemia and associated factors among school-age Children in filtu town, somali region, southeast Ethiopia. Biomed central, BMC hematology.

Kemenkes. (2013). Angka kecukupan gizi yang dianjurkan bagi bangsa indonesia. Kementrian Kesehatan Republik Indonesia: Jakarta

Kemenkes. (2013). Riset Kesehatan Dasar. Kementrian Kesehatan Republik Indonesia.: Jakarta.
Nawir, H. (2017). Intervensi Susu Tinggi Protein Terhadap Tingkat Konsumsi Zat Gizi Makro dan Status Gizi pada Kelompok Usia Dewasa. Institut Pertanian Bogor

Purnamasari, E. (2014). Optimasi Kadar Kalori dalam Makanan Pendamping Asi (MP-Asi). Institut Pertanian Bogor

Raisita, N. (2013). Efek Pemberian Makanan Tambahan Anak Sekolah (PMT-AS) Terhadap Peningkatan Prestasi Belajar di SD Negeri Banyuanyar III Kota Surakarta. Universitas Muhammadiyah Surakarta.

Ulasaswini, A. (2015). Pengembangan Pangan Lokal Kacang Gude (Cajanus Cajan) sebagai Alternatif PMT-AS dengan Sumber Protein dan Zat Besi dalam Pembuatan Kue Tradisional Baruasa di Kabupaten Jeneponto. Universitas Hasanuddin. 